\title{
IMPLEMENTASI VIRTUE ETHICS ARISTOTELES DI ERA KEKINIAN
}

\author{
Oleh: \\ Atika Yulanda* \\ Mahasiswi Pascasarjana UIN Sunan Kalijaga Yogyakarta \\ atikayulanda24@gmail.com
}

\begin{abstract}
Abstrak
Manusia adalah makhluk Tuhan yang diberikan potensi akal sehingga berbeda dengan makhluk Tuhan lainnya. Dengan adanya potensi akal yang diberikan kepada manusia, makai a mampu membedakan antara yang baik dengan yang buruk. Membedakan mana perbuatan yang sesuai dengan ajaran Islam dan yang menyimpang dari ajaran Islam. Namun, dewasa ini telah banyak ditemukan kejanggalan dalam tingkah laku manusia. Mereka kadangkala tidak ubahnya seperti makhluk lain yang tidak mempunyai akal. Akhlak manusia sekarang ini telah jauh berbeda dari ajaran Islam, bagaimana mereka seharusnya bersikap dengan orang tua dan lingkungan. Salah seorang tokoh Filsuf Yunani Kuno yaitu Aristoteles telah mengemukakan bagaimana seorang manusia dalam bertingkah laku dan bersikap. Etika keutamaan yang digagas oleh Aristoteles ini berupaya untuk membawa manusia kepada kebahagiaan yang hakiki dan mampu menjadi manusia yang sempurna. Etika keutamaan dilakukan dengan cara memilih jalan tengah antara dua ekstrim. Misalnya sikap penakut dan pengecut, maka jalan tengahnya yaitu berani. Selain itu, etika keutamaan Aristoteles dapat di implementasikan dalam kehidupan masyarakat sekarang ini. Bagaimana akhlak manusia sekarang, apakah telah sesuai dengan akhlak Rasulullah atau tidak. Adapun metode yang digunakan dalam penelitian ini adalah studi kepustakaan dimana penulis mencari dan mengolah sumber-sumber primer yang berasal dari karya Aristoteles dan juga sumber sekunder yang berhubungan dengan topikyang diteliti.
\end{abstract}

Kata Kunci: Manusia, Aristoteles, Etika Keutamaan

\section{A. Latar Belakang Masalah}

Kedudukan etika dalam kehidupan manusia menempati tempat yang penting, sebagai individu maupun masyarakat dan bangsa sebab jatuh bangunnya suatu masyarakat tergantung kepada 
bagaimana etikanya. Apabila etikanya baik, sejaterahlah lahir batinnya namun jika etikanya buruk maka rusaklah lahir dan batinnya. ${ }^{1}$

Etika secara bahasa berasal dari bahasa Yunani yaitu ethos yang berarti adat istiadat, perasaan batin, kecendrungan hati untuk melakukan perbuatan. Etika dapat didefinisikan sebagai ilmu yang mempelajari tentang segala soal kebaikan dalam hidup manusia, mengenai gerak gerik pikiran dan rasa yang dapat menjadikan pertimbangan perasaan sampai mengenai tujuannya yang merupakan perbuatan. Etika dalam hal ini terdiri dari dua jenis yaitu etika kewajiban dan etika keutamaan. Etika kewajiban berkaitan dengan prinsip dan moral yang berlaku bagi perbuatan manusia. Sedangkan etika keutamaan lebih mengacu kepada manusia itu sendiri maksudnya lebih menekankan being manusia.

Pembahasan terkait dengan etika keutamaan ini telah ada semenjak masa Yunani Klasik. Di antara tokohnya yaitu Sokrates ${ }^{2}$,

${ }^{1}$ Yatimin Abdullah, Pengantar Studi Etika, (Jakarta: RajaGrafindo Persada, 2006), cet. 1, h. 1

${ }^{2}$ Sokrates ialah seorang filsuf Yunani yang sangat perpengaruh dalam pemikiran filsafat Barat. Ia lahir di Athena pada tahun 470 SM dan menjadi generasi pertama dari tiga ahli filsafat besar dari Yunani selain Plato dan Aristoteles. Sepanjang hidupnya Sokrates tidak pernah meninggalkan karya tulisan sehingga sumber utama mengenai pemikiran Sokrates berasal dari muridnya yaitu Plato. Sokrates juga memberikan pandangannya terkait dengan etika. Ia memperhatikan soal-soal praktis dalam hidup manusia. Menurut Sokrates tujuan kehidupan manusia adalah mencapai kebahagiaan dan untuk mencapai kebahagiaan adalah dengan keutamaan atau
Plato dan Aristoteles. Sokrates dan Plato telah memulai terlebih dahulu pembahasan akan etika keutamaan yang mengemukakan tentang keutamaan itu dalam menjawab pertanyaan terkait sifat karakter seperti apakah yang membuat seseorang menjadi pribadi yang baik.

$$
\text { Sedangkan }
$$

Aristoteles sebagaimana yang dikenal sebagai seorang murid dari Plato mengemukakan bahwa etika keutamaan sangat bermanfaat bagi manusia. Manusia yang hendak mencapai kebahagiaan haruslah dengan mengacu kepada sifat-sifat keutamaan yang ada pada dirinya. Mengenai etika keutamaan ini atau Virtue Ethics ini dimuat dalam karya Aristoteles yang berjudul Nicomachean Ethics. ${ }^{3}$ Dalam karya ini Aristoteles menjelaskan mengenai etika keutamaan yang harus dimiliki oleh manusia. Manusia menurut Aristoteles tidak hanya mempertanyakan tentang apa yang harus ia lakukan namun juga menyelidiki tentang bagaimanan seharusnya ia bisa menjadi seseorang yang berbudi dan berakhlak. Berkaitan dengan hal tersebut, maka dalam makalah ini akan dikaji serta

Virtue. Salah satu pendirian Sokrates yang terkenal yaitu keutamaan adalah pengetahuan.

${ }^{3}$ Nicomachean Ethics merupakan salah satu karya Aristoteles yang memuat tentang etika. Menurut kesaksian tradisi, karya ini diberi nama Nicomachean Ethics karena disusun oleh anak dari Aristoteles yaitu Nikomakhos setelah ayahnya meninggal. Walaupun tidak ditulis langsung oleh Aristoteles namun berasal dari pengajaran Aristoteles di sekolahnya, Lykeion. Dalam karyanya Nicomachean Ethics ini banyak membahas etika keutamaan bagi manusia agar mencapai kebahagiaan tertinggi. 
dipelajari kembali mengenai etika keutamaan atau Virtue Ethics menurut Aristoteles.

\section{B. Rumusan Masalah}

Berangkat dari latar belakang masalah yang telah di paparkan sebelumnya, maka yang menjadi rumusan masalah dalam makalah ini adalah:

1. Apa yang dimaksud dengan Virtue Ethics atau Etika Keutamaan?

2. Bagaimana Aristoteles terhadap Etika Keutamaan?

3. Bagaimana Implementasi Virtue Ethics atau Etika Keutamaan Aristoteles di Era Kekinian?

\section{Metode Penelitian}

Metode penelitian dalam tulisan ini adalah library Research atau studi kepustakaan. Dimana peneliti mencari dan menganalisis buku-buku yang berkaitan dengan topik permasalahan. Sumber-sumber dalam penelitian ini dari buku primer Aristoteles dan dilengkapi dengan buku-buku yang berkaitan dengan tema yang di angkat. Selain itu, juga menggunakan sumber-sumber dari majalah, internet dan media lainnya sebagai penunjang dalam karya ini. Setelah menemukan dan menganalisis karya-karya dari Aristoteles, peneliti merumuskan dan menulis bagaimana konsep dari Etika Keutamaan tokoh tersebut.

\section{Biografi Aristoteles}

Aristoteles adalah seorang filsuf yang sangat berpengaruh dalam pemikiran Filsafat Yunani Kuno. Ia dilahirkan di kota Stageira, di wilayah Chalcidice, Thracia, Macedonia tengah tahun 384 SM. Ayahnya adalah seorang dokter pribadi Amyntas II dari Macedonia di kota Pella. Ketika Aristoteles berusia 15 tahun, ayahnya meninggal dunia dan ia diasuh oleh pamannya, Proxenus. $^{4}$

Ketika Aristoteles berusia 17 tahun, ia dikirim ke Athena untuk belajar di academia Plato ${ }^{5}$ dan sekaligus menjadi murid Plato. ${ }^{6}$ Ia menghabiskan waktu di sana selama 20 tahun sampai Plato meninggal dunia. Sepeninggalnya Plato, academia itu digantikan oleh kemenakannya yang bernama Speusippos. Pada saat itu juga Aristoteles meninggalkan Athena bersama murid-murid Plato lainnya seperti Xenokrates dikarenakan mereka kurang menyetujui pendapat Speusippos tentang filsafat dan matematika. Setelah kepergiannya meninggalkan Athena, Aristoteles mengunjungi Assos di pesisir Asia Kecil di mana Hermeias pada saat itu

\footnotetext{
${ }^{4}$ Franz Magnis Suseno, 13 Tokoh Etika Abad ke-20, (Yogyakarta: Kanisius, 2000), h. 27

${ }^{5}$ Plato merupakan seorang Filsuf Yunani Kuno yang dilahirkan pada tahun 428 SM dalam sebuah keluarga terkemuka di Athena. Ayahnya bernama Ariston dan ibunya Periktione. Setelah Ariston meninggal, ibunya menikah lagi dengan pamannya yaitu Pyrilampes. Ia dididik di rumah Pyirilampes yang merupakan seorang politikus yang termasuk kalangan Perikles. Dari salah satu sumber mengatakan bahwa Plato sendiri sejak ia masih kecil sudah mengenal Sokrates.

${ }^{6}$ Zainal Abidin, Pengantar Filsafat Barat, (Jakarta: Rajawali Press, 2011), h. 104
} 
yang menjadi penguasanya. Hermeias sendiri merupakan salah satu murid academia. Hermeias mengundang Aristoteles kesana dan menyambut mereka dengan gembira. Sebagai penghargaan kepada Aristoteles, ia kemudian menikahkan Aristoteles dengan salah seorang kemenakan nya yang bernama Pythias. ${ }^{7}$ Tak lama kemudian, Pythias meninggal dunia dan ia menikah lagi dengan Herpyllis dan dikaruniai seorang anak laki-laki yang diberi nama Nikomakhos.

Pada tahun 345 SM, Hermeias ditangkap dan dibunuh oleh tentara Parsi. Keadaan ini mendorong Aristoteles dan kawan-kawannya untuk melarikan diri dari Assos. Ia melarikan diri ke Mytilene yang tidak jauh dari Assos. Di sini ia bersama teman-temannya mengadakan riset dalam bidang biologi dan zoologi yang data-datanya dikumpulkan dalam bentuk buku yang berjudul Historia Animalium. ${ }^{8}$

Sebagaimana yang kita ketahui bahwa ayah Aristoteles merupakan seorang dokter pribadi Amyntas II dan dapat dikatakan juga bahwa Aristoteles sendiri juga dikenal baik dalam istana tersebut. Ini terlihat ketika Aristoteles diundang oleh raja Philippos dari Macedonia, anak dari Amyntas II untuk mengajarkan pendidikan anaknya Alexander yang saat itu berusia 13 tahun. Ia mengajarkan tentang Homeros dan penyair-penyair Yunani lainnya kepada Alexander. pada

\footnotetext{
${ }^{7}$ Muhammad Hatta, Alam Pikiran Yunani, (Jakarta: Universitas Indonesia Press, 1986), h. 117

${ }^{8}$ K. Bertens, Sejarah Filsafat Yunani: Dari Thales ke Aristoteles, (Yogyakarta: Kanisius, 1999), h. 155
}

tahun 340, tugas Aristoteles telah selesai di istana Pella dan pada akhirnya Alexander di usia 19 tahun telah mampu menggantikan ayahnya sebagai raja Macedonia. $^{9}$

Pada tahun 335 SM, setelah Alexander naik tahta kerajaan Aristoteles kembali ke Athena dan mendirikan sebuah akademi yang diberi nama Lykeion (dilatinkan: Lyceum) dikarenakan berada di daerah yang dipersembahkan kepada dewa Apollo Lykeios. Dengan semangat yang tinggi dari para muridnya, Arostoteles mendirikan sebuah perpustakaan yang mengumpulkan macam-macam menuskrip dan peta bumi dan juga membuka sebuah museum yang mengumpulkan semua benda yang menarik perhatian terutama dalam bidang biologi dan zoologi. Selain itu, Alexander juga memberikan sumbangan yang besar untuk membentuk koleksi itu dan memerintahkan semua pemburu, penangkap unggas dan nelayan dalam kerajaannya supaya mereka melaporkan kepada Aristoteles mengenai semua hasil yang menarik dari sudut ilmiah. ${ }^{10}$

Walaupun hubungan antara Aristoteles dan Alexander tampak begitu harmonis, namun Aristoteles menolak secara principil cara kediktatoran Alexander apalagi ketika ia menghukum mati saudara sepupu Aristoteles yang dituduh telah berkhianat. Keadaan ini membuat Aristoteles ingin membunuh

\footnotetext{
${ }^{9}$ K. Bertens, Sejarah Filsafat Yunani: Dari Thales ke Aristoteles, h. 155

${ }^{10}$ K. Bertens, Sejarah Filsafat Yunani: Dari Thales ke Aristoteles, h. 156
} 
Alexander namun ia mengurungkan niatnya karena hubungan yang erat dengan Alexander dan karena kepercayaan orang-orang Athena. Pada tahun 323 SM, Alexander meninggal dunia dan mengakibatkan adanya golongan anti Macedonia dengan maksud untuk melepaskan Athena dari kerajaan Macedonia. ${ }^{11}$ Aristoteles dituduh telah kurang ajar kepada dewa dikarenakan penelitianpenelitian yang telah ia lakukan. Kemudian Aristoteles melarikan diri ke Chalcis dan setelah satu tahun pelariannya tepatnya pada tahun 322 SM, ia mengalami kesakitan dan meninggal dunia. ${ }^{12}$

\section{E. Etika Keutamaan atau Virtue Ethics}

Etika keutamaan (Virtue Ethics) terdiri dari dua kata yaitu etika dan keutamaan. Secara etimologi, etika berasal dari kata Yunani yaitu Ethikos, ethos yang berarti adat, kebiasaan, praktek, akhlak, sikap, perasaan dan cara berpikir. Bentuk jamaknya ta etha. Sebagai bentuk jamak dari ethos, ta etha berarti adat kebiasaan atau pola pikir yang dianut oleh suatu kelompok orang yang disebut masyarakat atau pola tindakan yang dijunjung tinggi dan dipertahankan oleh masyarakat tersebut. ${ }^{13}$

Sedangkan keutamaan dalam bahasa Inggris yaitu Virtue dan dalam

${ }^{11}$ Muhammad Hatta, Alam Pikiran Yunani, h. 118

${ }^{12}$ Muhammad Hatta, Alam Pikiran Yunani, h. 119

${ }^{13}$ K. Bertens, Ringkasan Sejarah Filsafat, (Yogyakarta: PT Kanisius, 1975), h. 217
Bahasa Yunani yaitu Arete. ${ }^{14}$ Dalam Kamus Besar Bahasa Indonesia, keutamaan adalah keunggulan, keistimewaan, hal yang penting (terbaik, unggul). Menurut Magnis Suseno, keutamaan merupakan terjemahan untuk kata virtue yang diartikan sebagai kekuatan atau kemampuan. Kata utama juga menunjuk kepada kemampuan manusia untuk membawa diri sebagai manusia utuh, jadi tidak dipersempit secara moralistik kepada kesalehan. ${ }^{15}$

Keutamaan merupakan akhlak yang baik dan sebagaimana yang kita ketahui bahwa akhlak itu sendiri yaitu kehendak yang dibiasakan. Bila kehendak seseorang dengan membiasakan kepada sesuatu yang baik maka sifat ini disebut utama. Manusia utama adalah manusia yang mempunyai akhlak yang baik yang membiasakan dirinya melakukakan perbuatan yang sesuai dengan apa yang diperintahkan oleh akhlak. Dengan demikian, terdapat perbedaan antara keutamaan dan wajib. Keutamaan merupakan sifat jiwa sedangkan wajib adalah perbuatan luar. $^{16}$

Etika keutamaan merupakan etika yang tidak menyoroti perbuatan satu demi satu, apakah sesuai atau tidak dengan norma moral tetapi lebih menfokuskan manusia itu sendiri. Etika ini mempelajrai keutamaan (virtue) yang berarti sifat watak yang dimiliki oleh manusia.

14 Lorens Bagus, Kamus Filsafat, (Yogyakarta: Kanisius, 1996), h. 457

${ }^{15}$ Franz Magnis Suseno, 13 Tokoh Etika Abad ke-20, h. 199

${ }^{16}$ Ahmad Amin, Ethika: Ilmu Akhlak, terj. Farid Ma'ruf, (Jakarta: Bulan Bintang, 1975), cet. I, h. 216 
Etika ini tidak menyelidiki apakah perbuatan yang dilakukan manusia itu baik atau buruk melainkan apakah manusia itu sendiri orang baik atau buruk. ${ }^{17}$ Etika ini mengarahkan fokus perhatiannya pada being manusia yang berbeda dengan etika kewajiban ${ }^{18}$ yang menekankan doing manusia. Etika keutamaan ingin menjawab pertanyaan: What kind of person should I be? "saya harus menjadi orang yang bagaimana?",19

Keutamaan merupakan disporsi watak yang telah diperoleh seseorang dan memungkinkan dia untuk bertingkah laku baik secara moral. Seperti kemurahan hati merupakan suatu keutamaan yang membuat seseorang membagi harta bendanya dengan orang lain yang membutuhkan serta semua orang akan berpendapat bahwa tingkah laku yang seperti itu adalah baik dan terpuji. ${ }^{20}$

\section{F. Etika Keutamaan menurut Aristoteles}

Aristoteles merupakan salah seorang filsuf yang juga memberikan pandangannya terkait etika. Ia tidak hanya membahas filsafat logika, psikologi, filsafat alam, metafisika dan lainnya. Etika juga menjadi

\footnotetext{
${ }^{17}$ K. Bertens, Etika, (Yogyakarta: Kanisius, 2013), h. 166

${ }^{18}$ Etika kewajiban merupakan salah satu jenis etika yang mempelajari prinsip-prinsip dan aturan-aturan moral yang berlaku untuk perbuatan seseorang. Etika kewajiban adalah mencari jawaban dari pertanyaan pokok: What should I do? "saya harus melakukan apa?".

${ }^{19}$ Abd Haris, Etika Hamka: Konstruksi Etik Berbasis Rasional-Religius, (Yogyakarta: LKiS, 2010), cet. II, h. 121

${ }^{20}$ K. Bertens, Etika, h. 170
}

pokok pembahasan filsafat Aroistoteles. Etika yang dibahas oleh Aristoteles menyangkut etika keutamaan atau Virtue Ethics. ${ }^{21}$

Etika keutamaan Aristoteles merupakan suatu sikap batin yang dimiliki oleh manusia (Hexis Prohairetike). Setiap keutamaan atau kebajikan akan menjadikan baik sesuatu pada dirinya dan membuat fungsinya terlihat dengan tepat. ${ }^{22}$ Misalnya keutamaan mata adalah membuat mata dan fungsinya jadi baik karena penglihatan yang baik terkait dengan mata yang baik. Demikian juga keutamaan seekor kuda yang menjadikannya baik sebagai kuda karena baik dalam berlari, membawa penunggannya dan dalam berhadapan dengan musuhnya. Oleh karena itu, kebajikan atau keutamaan seorang manusia juga merupakan sifat yang akan menjadikannya sebagai seseorang yang baik dan menyebabkannya melakukan fungsinya secara baik. ${ }^{23}$

Tujuan hidup manusia menurut Aristoteles bukanlah mencapai kebaikan untuk kebaikan, melainkan merasakan kebahagiaan ${ }^{24}$.

\footnotetext{
${ }^{21}$ Aristoteles, Nicomachean Ethics, terj. Embun Kenyowati, (Jakarta: Teraju, 2004), cet. I, h. viii

${ }^{22}$ Franz Magnis Suseno, 13 Tokoh Etika Abad ke-20, h. 37

${ }^{23}$ Aristoteles, Nicomachean Ethics, h. 37

${ }^{24}$ Bahagia dalam bahasa Arab yaitu sa'adah artinya "keberuntungan" atau "kebahagiaan". Kebahagiaan dalam Bahasa Inggris yaitu eudaimonia. Tujuan manusia yaitu untuk mencapai kebahagiaan. Kebahagiaan itu bersifat subjektif. Adakalanya seseorang bahagia apabila ia sehat dan ada juga yang merasa bahagia melalui kedudukan atau kehormatan. Lihat Jalaluddin Rakhmat, Renungan-renungan
} 
Bagi seorang dokter kesehatanlah yang baik, namun bagi seorang pejuang kemenanganlah yang baik. Yang menjadi ukurannya adalah keguaan yang praktis, manusia tidak hanya mengetahui namun berbuat dan bertindak. Bukan untuk mengetahui apa budi itu namun supaya menjadi seseorang yang berbudi.

Berlakunya budi manusia bergantung kepada pertimbangan yang matang, artinya seseorang harus memiliki pertimbangan yang sehat, bisa menguasai diri, mampu mengadakan keseimbangan antara keinginan dan cita-cita. Penguasaan diri diperlukan dalam diri manusia. Adakalanya manusia tidak mampu menguasai dirinya dan adanya pertentangan antara pikiran dan perbuatan. Manusia kadang-kadang melakukan perbuatan di luar akal sehat serta dikuasai oleh naluri kehewanan yang bersarang di dalam tubuhnya. ${ }^{26}$

Manusia dalam kehidupan sehari-hari pasti mengejar suatu tujuan yang hendak dicapai. Ia selalu mencari sesuatu yang baik baginya. Menurut Aristoteles, tujuan tertinggi manusia adalah kebahagiaan. Namun, kebahagiaan antara satu orang dengan orang lain berbeda, ada yang mengatakan bahwa kebahagiaannya adalah kesehatan, dan ada pula yang mengatakan kebahagiaan setara dengan penghormatan yang diperoleh dalam perlombaan-perlombaan di

Sufistik: Membuka Tirai Kegaiban, (Bandung: PT Mizan Pustaka, 1994), h. 205

${ }^{25}$ Muhammad Hatta, Alam Pikiran Yunani, h. 132

${ }^{26}$ Muhammad Hatta, Alam Pikiran Yunani, h. 133
Olympia, orang yang merasa dirinya hina memandang bahwa kebahagiaan terletak pada kemuliaan dan kekuasaan. $^{27}$ Oleh karena itu, menurut pandangan Aristoteles kebahagiaan itu harus disamakan dengan suatu aktivitas bukan dengan potensialitas belaka. Seseorang mendapatkan kesempurnaannya bukan karena potensi yang begitu saja, melainkan karena potensi sudah mencapai aktualisasinya. ${ }^{28}$ Tidak mungkin seseorang mencari kebahagiaan orang lain dalam suatu aktivitas yang terdapat juga pada makhluk-makhluk yang bukan manusia. Kebahagiaan manusia terkait akan suatu aktivitas yang khusus untuk manusia saja dan mengakibatkan kesempurnaannya. Misalkan kesempurnaan mata ialah untuk melihat. ${ }^{29}$

Kesempurnaan manusia adalah aktualisasi dari kemungkinan tertinggi yang hanya terdapat dalam diri manusia saja seperti rasio. Itulah sebabnya kebahagiaan manusia sama saja dengan menjalankan aktivitas yang spesifik baginya yaitu pemikiran. Bagi manusia kebahagiaan ialah memandang kebenaran. Namun, agar manusia bahagia tidak hanya dengan melakukan aktivitas tertinggi manusia yang dijalankan dengan sembarangan saja. Manusia disebut bahagia apabila ia telah mampu menjalankan aktivitasnya dengan

\footnotetext{
${ }^{27}$ Ibnu Miskawaih, Tahdzibul Al- Akhlaq, terj. Helmi Hidayat: Menuju Kesempurnaan Akhlak, (Bandung: Mizan. 1998), h. 94

${ }^{28}$ Louis O. Kattsoff, Elements Of Philosophy, terj. Soejono Soemargono, (Yogyakarta: Tiara Wacana, 1987), h. 364

${ }^{29}$ Aristoteles, Nicomachean Ethics, h. 15
} 
baik. Atau seperti yang diungkapkan oleh Aristoteles bahwa jika manusia hendak bahagia ia harus menjalankan aktivitasnya menurut keutamaan. Hanya dengan pemikiran yang disertai keutamaan yang mampu mengantarkan manusia kepada kebahagiaan. ${ }^{30}$

Manusia tidak hanya makhluk intelektual namun juga makhluk yang mempunyai perasaan, keinginan, nafsu-nafsu dan lain sebagainya. Oleh karena itu menurut Aristoteles terdapat dua macam keutamaan yaitu keutamaan intelektual dan keutamaan moral. ${ }^{31}$ Sebagaimana dikutip dari pendapat Peter Singer:

"Intellectual virtue in the main owes both its birth and its growth to teaching (for which reason it requires experiences and time), while moral virtue comes about as a result of habit, whence also its name is one that is formed by a slight variation from the word (habit). From this it is also plain that none of the moral virtues arises in us by nature for nothing that exist by nature can from a habit contrary to its nature. "32

\section{Keutamaan Intelektual \\ Keutamaan intelektual berasal dan berkembang karena}

pengajaran. ${ }^{33}$ Menurut pandangan Aristoteles, rasio manusia mempunyai dua fungsi yaitu di satu pihak rasio memungkinkan manusia untuk mengenal kebenaran. Maksudnya adalah rasio boleh disebut sebagai rasio teoritis. Di lain pihak, rasio dapat memberikan petunjuk supaya orang mengetahui apa yang harus diputuskan dalam keadaan tertentu. Dalam hal ini rasio boleh disebut sebagai rasio praktis. ${ }^{34}$

Oleh karena itu, Aristoteles membedakan kepada dua macam keutamaan yang menyempurnakan rasio. Pertama, kebijaksanaan teoritis. Kebijaksaan ini merupakan suatu sikap tetap dan tidak boleh dilakukan dengan hanya sekali pengenalan. Kebijaksanaan teoritis ditempuh dengan suatu jalan yang panjang yang meliputi seluruh pendidikan ilmiah. Kedua, kebijaksanaan praktis. Kebijaksanaan ini merupakan sikap jiwa yang memungkinkan manusia untuk mengatakan mana sesuatu yang konkret yang dianggap baik untuk hidupnya. Seseorang yang memiliki kebijaksanaan praktis jika ia mampu memperhitungkan sesuatu dengan baik dalam hubungannya dengan tujuan yang bernilai yang tidak dapat dicapai oleh ilmu pengetahuan terapan atau seni. Oleh karena itu, secara umum orang yang memiliki kebijaksanaan praktis adalah yang memiliki kemampuan untuk mempertimbangkan. ${ }^{35}$

\footnotetext{
${ }^{30}$ Aristoteles, Nicomachean Ethics, h. 19

${ }^{31}$ Franz Magnis Suseno, 13 Tokoh Etika Abad ke-20, h. 38

${ }^{32}$ Peter Singer, Ethics, (New York: Oxford University Press, 1994), h. 26
}

\footnotetext{
${ }^{33}$ Aristoteles, Nicomachean Ethics, h. 29

${ }^{34}$ K. Bertens, Sejarah Filsafat Yunani: Dari

Thales ke Aristoteles, h. 198

${ }^{35}$ Aristoteles, Nicomachean Ethics, h. 148
} 
Budi pekerti, seperti kebijaksanaan, kecerdasan, dan pendapat yang sehat lebih diutamakan oleh Aristoteles dibandingkan dengan budi perangai seperti keberanian, kesederhanaan, pemurah hati dan lainnya. Setiap budi perangai yang baik harus duduk sama tengah antara dua sikap yang paling jauh tantangannya. Misalkan seseorang yang berani berada antara pengecut dan nekat, suka memberi antara kikir dan boros. Budi itu terdapat antara manusia karena perbuatan mereka. ${ }^{36}$

\section{Keutamaan Moral}

Keutamaan moral dibentuk oleh kebiasaan, etos dan istilah etik. Menurut Aristoteles keutamaan moral sebagai suatu sikap yang memungkinkan manusia untuk memilih jalan tengah antara dua ekstrem yang berlawanan. ${ }^{37}$ Oleh karena itu keutamaan moral adalah jalan tengah. Misalnya, seseorang yang hendak membelanjakan uangnya. Dalam hal ini, terdapat dua ekstrem yaitu di satu pihak seseorang dapat mengeluarkan uang terlalu banyak dan di lain pihak orang juga dapat mengeluarkan uang yang terlalu kurang. Seseorang yang mengeluarkan uang yang berlebih dapat dikatakan pemboros, namun yang satunya lagi dapat dikatakan seseorang yang terlampau hemat atau kikir. Keutamaan dalam hal membelanjakan uang dapat memilih jalan tengah antara dua ekstrem itu

${ }^{36}$ Muhammad Hatta, Alam Pikiran Yunani, h. 133

${ }^{37}$ Ahmad Amin, Ethika: Ilmu Akhlak, h. 223 dan inilah keutamaan yang kita sebut dengan kemurahan hati. ${ }^{38}$

Contoh lainnya adalah dalam hal kepercayaan diri. Ada orang yang terlalu percaya diri dan disebut dengan gegabah. Namun, ada juga yang terlampau kurang percaya diri dan disebut dengan pengecut. Oleh karenanya dalam hal percaya diri terdapat dua sikap ekstrem yang masing-masing disebut kegegabahan dan sifat pengecut. Di sini juga ada kemungkinan suatu keutamaan yang memilih jalan tengah antara kedua ektrem tersebut yaitu keberanian atau kegagahan.

Dalam keutamaan moral, manusia dituntut untuk memilih jalan tengah antara dua ekstrim yang saling berlawanan. Namun, selain jalan tengah terdapat tiga hal yang harus di miliki manusia untuk mencapai kebahagiaan. Pertama, manusia harus memiliki harta secukupnya supaya hidupnya terpelihara. Kedua, alat yang terbaik untuk mencapai kebahagiaan manusia adalah persahabatan. Karena sebagaimana yang diketahui manusia merupakan makhluk sosial yang tidak mampu hidup sendiri dan membutuhkan orang lain. Oleh karena itu kehadiran makhluk lainnya akan membantu manusia mencapai kebahagiaan. Ketiga, keadilan. Keadilan ini juga mencakup sebagai sesuatu yang mampu mengantarkan manusia menuju kebahagiaan. Hal ini dikarenakan manusia yang sempurna merupakan manusia yang mampu memberikan sesuatu sesuai dengan kadar dan tempatnya. Jika mereka

\footnotetext{
${ }^{38}$ K. Bertens, Sejarah Filsafat Yunani: Dari Thales ke Aristoteles, h. 197
} 
berat sebelah maka tidak akan menemukan kebahagiaan dan kepercayaan dari orang lain. ${ }^{39}$

Aristoteles dalam karyanya tentang etika mengemukakan empat macam keutamaan pokok atau Cardinal Virtue yaitu kebijaksanaan, jalan tengah, keadilan dan kesederhanaan. Keempat keutamaan itu akan mengantarkan manusia kepada tujuan pokok yang hendak dicapai yaitu kebahagiaan dan kesuksesan. Kebahagiaan akan dicapai apabila manusia melaksanakan etika kebaikan dan menjadi manusia yang bermanfaat bagi orang lain.

Menurut Aristoteles, seseorang yang dapat dikatakan betul-betul mempunyai keutamaan tidak hanya terfokus hanya sekali atau dua kali memilih jalan tengah antara dua ekstrem. Keutamaan baru dikatakan yang sungguh-sungguh apabila seseorang mempunyai sikap yang tetap untuk memilih jalan tengah tersebut. Jalan tengah tidak bisa disamakan antara satu orang dengan orang lain karena penentuan jalan tengah itu bersifat subjektif bukan objektif. Misalkan seseorang yang ekonominya tipis barangkali sudah dianggap murah hati jika ia mendermawankan tidak lebih dari sepuluh rupiah kepada seseorang pengemis sedangkan orang kaya barangkali dianggap kikir jika memberi derma sebesar sepuluh ribu rupiah. $^{40}$

\footnotetext{
${ }^{39}$ Mohammad Hatta, Alam Pikiran Yunani, h. 134

${ }^{40}$ Aristoteles, Nicomachean Ethics, h. 41
}

Diantara keutamaan moral menurut Aristoteles yaitu:

a. Tanggung Jawab

Sebagai keutamaan moral, tanggung jawab pertama-tama merupakan sikap terhadap tugas yang telah dibebani terhadap sesorang oleh orang lain. Bagaimana tanggung jawabnya terhadap tugas dan kepercayaan yang telah diamanahkan kepadanya. Dalam implikasinya, tanggung jawab tidak pernah memberi ruang untuk sikap-sikap seperti malas, acuh tak acuh dan ragu-ragu. Sikap bertanggung jawab menuntut seseorang untuk melakukan sesuatu dengan sebaik-baiknya. ${ }^{41}$

Pribadi yang bertanggung jawab merupakan orang-orang yang selalu bersedia untuk dimintai dan memberikan pertanggungjawaban atas pelaksanaan tugas dan kewajibannya, termasuk ketika ia lalai dalam pelaksanaan tugas dan tanggung jawab. Orang-orang yang bertanggung jawab akan senantiasa siap untuk menjadi good risk-taker. Mereka tidak akan pernah melemparkan tanggung jawab itu kepada orang lain yang tidak bersalah. $^{42}$

\section{b. Keberanian Moral}

Keberanian yang dimaksudkan di sini yaitu seseorang yang mampu untuk menentukan sikap untuk bertindak. Keberanian moral akan berhubungan dengan kemampuan intelektual untuk menentukan penilaian-penilaian sendiri terhadap sesuatu. Dalam

\footnotetext{
${ }^{41}$ Aristoteles, Nicomachean Ethics, h. 61

${ }^{42}$ K. Bertens, Etika, h. 99
} 
situasi yang berbahaya, orang yang berani dengan mudah mengambil posisi tengah antara sikap pengecut (kurang berani) dan sikap gegabah (terlalu berani). ${ }^{43}$

Misalkan dalam sebuah bisnis, keberanian moral mewujudkan tekad diri dalam tekad pebisnis, manajemen, dan karyawan untuk mempertahankan sikap-sikap yang telah diyakini sebagai kewajiban termasuk ketika tidak disetujui oleh lingkungan sekitar. Mereka ini dapat dikatakan memiliki keberanian moral apabila ia tidak dapat digoyahkan oleh berbagai celaan, hinaan yang datang dari lingkungan luar terhadap dirinya dan tidak pernah mundur dari tugas yang telah diamanahkan.

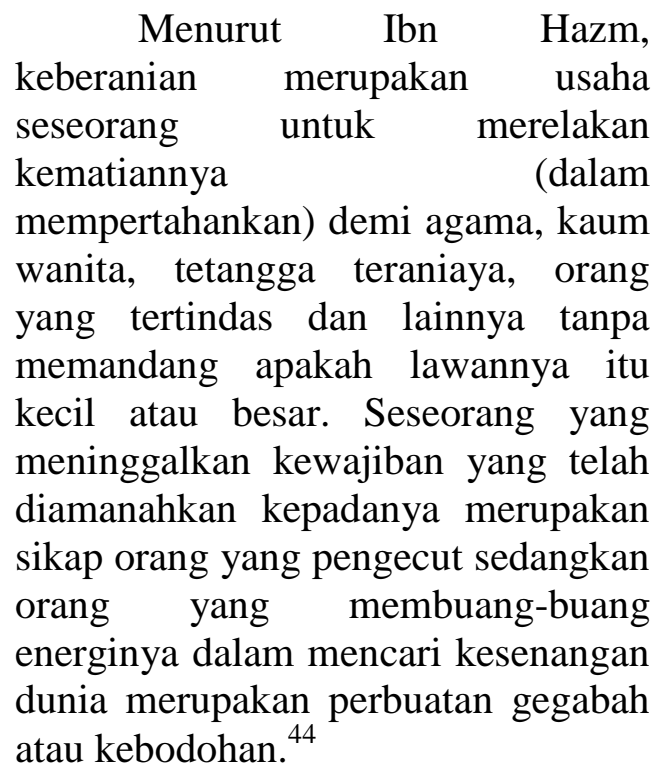

\section{c. Kedermawanan}

Dermawan merupakan jalan tengah dalam wilayah benda, materi

\footnotetext{
${ }^{43}$ Aristoteles, Nicomachean Ethics, h. 68

${ }^{44}$ Majid Fakhry, Ethical Theories in Islam, terj. Zakiyuddin Baidhawy: Etika dalam Islam, (Yogyakarta: Pustaka Pelajar, 1996), cet. I, h. 98
}

atau harta benda. Seseorang dipuji sebagai dermawan tidak untuk apa yang dilakukannya di medan pertempuran melainkan karena pemberian dan penerimaan akan harta benda khusunya dengan pemberian. Yang dimaksud dengan harta benda disini yaitu yang berhubungan dengan uang. ${ }^{45}$

Kedermawanan adalah jalan tengah antara pemberian dan penerimaan harta benda, orang yang dermawan akan memberi dan menghabiskan jumlah yang tepat terhadap objek yang tepat, dalam hal kecil atau besar secara sama serta ia akan memperoleh kesenangan tersendiri dari perbuatan tersebut. Ia juga akan mengambil jumlah yang tepat dari sumber yang benar.

Kedermawanan didefinisikan sebagai sikap seseorang yang menafkahkan kelebihan harta demi kebajikan khususnya menolong orang yang membutuhkan misalnya orang miskin dan orang yang terlantar. Seseorang yang menyembunyikan pemberian dalam segala hal merupakan bentuk penganiayaan sedangkan memberikan dalam berbagai juga merupakan bentuk pemborosan yang tercela. Di luar semua itu merupakan kemurahan hati atau memberikan apa yang kita miliki kepada orang yang benar-benar lebih membutuhkannya daripada kita sendiri. $^{46}$

d. Tulus, pembual, dan memandang rendah diri sendiri

\footnotetext{
${ }^{45}$ Aristoteles, Nicomachean Ethics, h. 81

${ }^{46}$ Majid Fakhry, Ethical Theories in Islam, terj. Zakiyuddin Baidhawy: Etika dalam Islam,..
} 
Pembual adalah seseorang yang berpura-pura mempunyai kualitas yang membawa mereka pada prestise tinggi, meskipun ia tidak memilikinya. Seorang penipu diri sendiri sebaliknya menyembunyikan dan mengurangi kualitas yang ia miliki. Sementara itu ada orang yang berada di posisi tengah yaitu orang yang menyebut sesuatu sesuai dengan sebutan yang sesungguhnya. Ia tulus dalam hidup dan perkataannya. Ia selalu menunjukkan kualitas yang ada dalam dirinya tanpa dilebih-lebihkan dan dikurang-kurangkan. ${ }^{47}$

Orang yang tulus diibaratkan sebagai orang yang jujur karena ia lebih mencintai kebenaran yang ada dibanding hidup dipenuhi kebohongan.

\section{e. Rendah Hati}

Rendah hati disini bukan berarti seseorang merendahkan diri melainkan ia melihat dirinya sesuai dengan yang ada. Kerendahan hati merupakan kekuatan batin untuk melihat kelemahannya, melainkan juga kekuatannya. Tetapi ia tahu bahwa apapun yang dikagumi orang lain terhadap dirinya hanyalah kebetulan semata. Ia menyadari kemampuan dan kebaikannya terbatas dan ia ikhlas menerima itu semua. $^{48}$

\section{f. Keadilan}

Adil merupakan suatu sifat yang tidak berat sebelah maksudnya jika seseorang mengambil haknya

${ }^{47}$ Aristoteles, Nicomachean Ethics, h. 104

${ }^{48}$ Frans Magnis Suseno, Etika Dasar: Masalah-masalah Pokok Filsafat Moral, (Yogyakarta: Kanisius, 1987), h. 148 dengan tidak melebihi dan memberi hak-hak orang lain dengan tidak menguranginya. Maksudnya disini adalah menempatkan sesuatu pada tempatnya dan tidak merugikan diri sendiri dan orang lain. Lawan dari kata adil yaitu berat sebelah yaitu seseorang yang berkeinginan kepada sebuah benda yang sama dan mengambil haknya lebih besar sedangkan ia memberikan hak orang lain dengan sedikit. Tidak adanya pembagian yang sama rata antara ia dengan orang lain. ${ }^{49}$

Adil merupakan titik tengah antara berbuat lalim dengan dilalimi. Orang yang berbuat lalim apabila ia memperoleh banyak harta dari sumber yang salah dan dengan cara yang salah. Sedangkan orang yang dilalimi adalah orang yang tunduk dan memberikan respon pada orang yang salah serta dengan cara yang salah. Orang yang adil berdiri di tengah karena ia memberikan hartanya dengan cara yang benar serta ditinggalkannya cara-cara yang salah. Oleh karena itu, adil merupakan suatu kebajikan yang menyebabkan seseorang adil terhadap dirinya dan orang lain dengan tidak memberikan lebih banyak sesuatu yang bermanfaat untuk dirinya sendiri dan sedikit kepada orang lain. $^{50}$

Seorang pedagang yang memberikan barang dagangannya kurang dari timbangan yang telah ditetapkan, maka ia merupakan seorang pedagang yang dzalim karena ia tidak memberikan yang hak

\footnotetext{
${ }^{49}$ Ahmad Amin, Ethika: Ilmu Akhlak, h. 250

${ }^{50}$ Ibnu Miskawaih, Tahdzibul Al-Akhlaq, h. 53
} 
kepada yang berhak menerimanya yaitu pembeli. ${ }^{51}$

\section{g. Persahabatan}

Menurut

Aristoteles

persahabatan merupakan salah satu jenis keutamaan, kebajikan yang tidak dapat dihindari dalam hidup. Tidak dapat dipungkiri bahwa manusia dalam kehidupannya pasti membutuhkan orang lain, sekalipun ia telah mempunyai banyak uang dan kekuasaan pasti ia akan membutukan seorang teman atau sahabat. Manusia saling membutuhkan demi kelangsungan hidupnya. ${ }^{52}$

Persahabatan yang sempurna adalah persahabatan antara orang baik yang sama dalam keutamaan dan kebajikan. Mereka manjalin persahabatan tidak hanya mengandalkan manfaat semata namun karena mereka sama-sama merasa senang dan saling berbagi dalam suka maupun duka. Persahabatan yang seperti ini hanya mampu dilakukan oleh orang yang memiliki akhlak yang baik dan keutamaan yang mulia. Karena kebanyakan dari mereka hanya mengambil keuntungan dari orang lain. ${ }^{53}$

Hubungan timbal balik antara seseorang dengan orang lain akan menumbuhkan suatu ikatan yang sangat indah. Adakalanya akan menumbuhkan rasa cinta dan kasih sayang yang membawa mereka kepada ikatan persaudaraan. Cinta disini terbagi menjadi beberapa jenis.

${ }^{51}$ Bachtiar Affandie, Achlak, (Jakarta: Djambatan, 1960), cet. II, h. 256

${ }^{52}$ Aristoteles, Nicomachean Ethics, h. 205

${ }^{53}$ Aristoteles, Nicomachean Ethics, h. 210
Pertama, cinta yang terjalin dengan cepat tapi pupusnya cepat misalnya cinta karena kenikmatan. Kedua, cinta yang terjalin dengan cepat tapi pupusnya lambat seperti kebaikan. Ketiga, cinta yang terjalin lambat, namun pupusnya cepat seperti cinta karena manfaat semata. Terakhir, cinta yang terjalin lambat dan pupusnya juga lambat seperti perpaduan antara sebab-sebab di atas. $^{54}$

Sebuah persahabatan yang baik merupakan bagian dari cinta. Seseorang yang merasa nyaman dan selalu berbagi cerita dengan orang lain akan melahirkan sifat kasih sayang dan adanya perasaan senang apabila berada di dekat mereka. ${ }^{55}$ Namun, adakalanya persahabatan yang terjalin antara satu orang dengan orang lain, antara anak-anak remaja didorong oleh kenikmatan dan manfaat. Inilah yang tidak dibolehkan dalam ajaran-ajaran Islam. Seharusnya persabahatan yang terjalin alangkah lebih baiknya didasarkan oleh perasaan yang tulus dan tanpa memandang apapun.

\section{G. Implementasi Virtue Ethics atau Etika Keutamaan Aristoteles di Era Kekinian}

Sebagaimana yang diketahui, Aristoteles merupakan seorang tokoh filsafat Yunani yang sangat mempengaruhi kepada pemikiran tokoh filsafat setelahnya. Pemikiran Aristoteles khususnya terkait etika sangat mempengaruhi para filosof Muslim seperti Ibnu Miskawaih dan

\footnotetext{
${ }^{54}$ Ibnu Miskawaih, Tahdzibul Al-Akhlaq, terj. Helmi Hidayat, h. 133

${ }^{55}$ Ibnu Miskawaih, Tahdzibul Al-Akhlaq, terj. Helmi Hidayat, h. 134
} 
lainnya. ini dapat dilihat dalam karyakarya Ibnu Miskawaih yang mencantumkan dan menjabarkan bagaimana etika Aristoteles. Konsep etikanya yang menarik yaitu terkait dengan Virtue Ethics atau etika keutamaan. Di sini, ia mencoba menjelaskan tentang manusia sempurna yang mampu mencapai kebahagiaannya. Etika keutamaan Aristoteles sebagaimana yang telah dipaparkan di atas, berkaitan dengan perilaku manusia dalam mengambil jalan tengah. Jalan tengah di sini dijelaskan Aristoteles sebagai suatu sikap manusia dalam memilih antara dua ekstrim seperti pemberani yang berada antara pengecut dan gegabah. Seseorang yang mempunyai etika keutamaan akan mampu mengambil jalan tengah antara dua ekstrim yang berlawanan dan mencapai kebahagiaan.

Di Era Modern atau Kekinian, banyak kita temukan manusia yang berusaha menjadi seorang pahlawan terhadap manusia lain padahal apabila ia telah dihadapkan langsung dengan masalah yang ada, kebanyakan dari mereka lari dan tidak akan bertanggung jawab. Seperti pepatah orang "pahlawan kesiangan". Di sinilah letak peranan dari etika keutamaan Aristoteles. Seseorang yang sempurna dan dapat mencapai kebahagiaan adalah ia yang mampu melakukan suatu kebaikan tanpa adanya paksaan dan suatu imbalan. Seperti sikap dermawan, apabila seseorang ikhlas dan tidak ada sesuatu apapun pasti dalam hatinya akan merasakan kebahagiaan dan ketenangan. Berbeda dengan yang kita lihat pada sekarang ini, kebanyakan mereka melakukan suatu kebaikan dengan adanya suatu paksaan dan ingin dipuji orang lain. Menurut Aristoteles, jika ingin menjadi manusia yang sempurna haruslah ditanamkan sikap rendah hati, dermawan, berani dan bertanggungjawab.

\section{H. Kesimpulan}

Dari uraian yang sederhana di atas dapat diketahui bahwa Aristoteles adalah seorang filosof Yunani Klasik yang sangat berpengaruh dalam perkembangan pemikiran Filsafat. Pemikiran filsafatnya terdiri dari filsafat alam, metafisika, logika dan etika.

Etika yang digagas oleh Aristoteles adalah etika keutamaan atau Virtue Ethics. Keutamaan disini terbagi menjadi keutamaan intelektual dan keutamaan moral. Keutamaan intelektual berhubungan dengan akal dan rasio yang dimiliki manusia. Manusia dengan kemampuan akalnya mampu membedakan mana yang baik dan mana yang buruk serta mampu mempertimbangkan setiap perbuatan yang ia lakukan. Sedangkan keutamaan moral berhubungan dengan pilihan manusia dalam pengambilan jalan tengah. Manusia harus mampu mengambil jalan tengan dari suatu perbuatan agar menjadi manusia yang sempurna. Kebahagiaan merupakan tujuan dari setiap manusia, dan untuk memperoleh itu manusia dituntut untuk memperoleh pengetahuan dan mengaplikasikan akhlak-akhlak yang baik dalam kehidupan sehari-hari. 


\section{Daftar Kepustakaan}

Aristoteles. 2004. Nicomachean Ethics, terj. Embun Kenyowati. Jakarta: Teraju.

Abdullah, Yatimin. 2006. Pengantar Studi Etika. Jakarta: RajaGrafindo Persada.

Abidin, Zainal. 2011. Pengantar Filsafat Barat. Jakarta: Rajawali Press.

Affandie, Bachtiar. 1960. Achlak. Jakarta: Djambatan.

Amin, Ahmad. 1975. Ethika: Ilmu Akhlak, terj. Farid Ma'ruf. Jakarta: Bulan Bintang.

Bagus, Lorens. 1996. Kamus Filsafat. Yogyakarta: Kanisius.

Bertens, K. 1975. Ringkasan Sejarah Filsafat. Yogyakarta: PT Kanisius.

1999. Sejarah Filsafat Yunani: Dari Thales ke Aristoteles. Yogyakarta: Kanisius.

2013. Etika. Yogyakarta: Kanisius.

Fakhry, Majid. 1996. Ethical Theories in Islam, terj. Zakiyuddin Baidhawy: Etika dalam Islam. Yogyakarta: Pustaka Pelajar.
Haris, Abd. 2010. Etika Hamka: Konstruksi Etik Berbasis Rasional-Religius. Yogyakarta: LKiS.

Hatta, Muhammad. 1986. Alam Pikiran Yunani. Jakarta: Universitas Indonesia Press.

Miskawaih, Ibnu. 1998. Tahdzibul AlAkhlaq, terj. Helmi Hidayat: Menuju Kesempurnaan Akhlak. Bandung: Mizan.

Kattsoff, Louis O. 1987. Elements Of Philosophy, terj. Soejono Soemargono.

Yogyakarta: Tiara Wacana.

Suseno, Frans Magnis. 1987. Etika Dasar: $\quad$ Masalah-masalah Pokok Filsafat Moral. Yogyakarta: Kanisius. 2000. 13 Tokoh Etika Abad ke-20. Yogyakarta: Kanisius.

Yosephus, Sinour. 2010. Etika Bisnis: Pendekatan Filsafat Moral terhadap Perilaku Pebisnis Kontemporer. Jakarta: Yayasan Pustaka Obor Indonesia.

Rakhmat, Jalaluddin. 1994. Renungan-renungan Sufistik: Membuka Tirai Kegaiban. Bandung: PT Mizan Pustaka. 